\title{
The Impact of Optional Preferential Voting on the 2001 Queensland State Election
}

\author{
Stephen Stockwell
}

\begin{abstract}
During the 2001 Queensland state election, the Australian Labor Party's (ALP) 'Just Vote I' campaign message sought to limit preference exchange among conservative parties. This paper analyses the impact of this tactic that produced a 53.6 per cent increase in the exhausted vote over the last election. The size of the landslide to Labor made this tactic irrelevant but it affected the outcome in five seats and could have been decisive in a closer election. The concern is raised that the optional preferential system produces a less representative and less democratic outcome than the compulsory preferential system.
\end{abstract}

\section{Introduction}

Preferential voting (sometimes called 'instant run-off or 'second choice' voting in the United States, 'supplementary' voting in the United Kingdom or 'alternative' voting internationally), allows electors to record their support for candidates in rank order (1,2,3 etc.). To win, a candidate must secure an absolute majority (50 per cent plus one) of the vote. Where no candidate has a majority of the primary vote, then the candidate with least votes is eliminated and their second preferences distributed and so on until one candidate has an absolute majority.

The preferential system addresses the problem of 'split voting', or what Charles Dodgson called 'cyclical majorities' (Black 1958: 227). The problem is that firstpast-the-post elections are decided on voters' first preferences so that where there are three or more candidates, the candidate with the most votes may not be preferred by the majority of electors. Preferential voting ensures that the candidate preferred by an absolute majority of the voters wins, eliminating the possibility of winners with only minority support. It is an alternative to the run-off ballot used in France, 
where if no candidate has an absolute majority in the first round of voting, then a subsequent election is held between the two candidates who won the most votes.

Preferential voting has been a feature of Australian politics since the 'contingent' vote was introduced in Queensland in 1892 (ECQ 2001: A17; Reilly 1997: 3; Wright 1980: 58). Under the contingent system if no candidate has a majority of primary votes, the preferences from all other candidates are distributed to the two candidates with the greatest vote (Reilly 1997: 3). Full preferential voting was introduced in Western Australia in 1907 and Victoria in 1911. In 1918 preferential voting was introduced in federal elections for the House of Representatives, where it is still used. In Queensland, contingent voting was discarded in 1942 in favour of first-past-the-post voting and then full preferential voting was introduced in 1962 (ECQ 2001: A17). Now all State lower houses utilise preferential voting except Tasmania. The allocation of preferences is also available in the single, transferable vote system of proportional representation used in Australian Senate elections, though the vast majority of electors choose to make just one mark 'above the line' to vote for a party ticket and that party's preferences.

Preferential voting means that voters can support minor parties and independent candidates without 'wasting' their vote, knowing that their preferences may be used to decide the winner. But it allows parties to 'exchange preferences' which has historically promoted a centrist, two-party system. The compulsory preferential voting system has been criticised because voters are forced to express a preference for candidates they abhor or know nothing about which has led to the adoption of optional preferential voting in New South Wales in 1981 and Queensland in 1992 (Reilly 1997: 6). For more on the case made for optional preferential voting in New South Wales see Adams (1979) and in Queensland see the Electoral and Administrative Review Commission (EARC) report (1990: 50-59).

\section{Queensland 2001}

Pauline Hanson's One Nation Party emerged as a political force in the 1998 Queensland election when it garnered 22.68 per cent of the primary vote and 11 seats in the 89-seat Legislative Assembly. One Nation splintered the conservative vote and many of Hanson's supporters made use of Queensland's optional preferential system to let their vote exhaust rather than go to any other party. The ALP formed a minority government with the support of an independent.

After that election, Liberal Santo Santoro advocated a return to compulsory preferential voting, arguing that the optional preferential system had 'by default brought Labor to power' because many One Nation voters had chosen not to allocate their second preferences which, Santoro believed, would have favoured the Coalition (Wanna 1999: 572).

Within the ALP there was also a realisation that if first past the post voting had applied, Labor would have led the way in 55 seats and produced a landslide. A determination arose in the ALP to utilise this phenomenon and the 'Just Vote 1' strategy and slogan was trialled in by-elections in Mulgrave in 1998 and Bundamba 
and Woodridge in 2000. This advice to voters to only give a first preference was particularly effective in the Woodridge by-election where it deadened the flow of minor candidate preferences to a popular local independent who was challenging the ALP in its once-safe stronghold.

In early 2001, Queensland's ALP government was in dire straits. The Shepherdson inquiry into false electoral enrolments had led to the resignation of the deputy Premier and two backbenchers with ministerial prospects. The government no longer had a majority on the floor of parliament so, to avoid an embarrassing defeat, an election had to be called before parliament sat. In the event, Premier Peter Beattie came out with an action plan to end 'rorting' in the ALP thus turning the issue to his advantage. The impact of One Nation produced dissension between and within the conservative parties and the ALP heightened the effect of this dissension by unleashing its 'Just Vote 1' strategy. The result was a landslide to the ALP which won 48.93 per cent of the primary vote and 66 seats compared to 12 seats to the Nationals, three each to the Liberals and One Nation and five to independents (see Table 1).

\section{Measuring the Just Vote 1 Effect}

Labor's 'Just Vote 1' slogan was already part of Premier Beattie's mantra at the start of the campaign (Franklin 2001: 8) and it was reinforced by a skillfully constructed television advertisement. The visual element of the advertisement is a mock ballot paper with, instead of names, the phrases 'My Party', 'Their Party' and 'Some Other Party'. As two male voices talk about voting options, numbers are added to, and then taken away from the ballot paper. Finally the voices decide that they could just vote 1 for Labor. It is only in the last seconds that it becomes clear that it is an ALP advertisement. While technically only advising Labor supporters on what to do with their preferences, the advertisement was equally persuasive to conservative and minor party supporters. In the final week of the campaign, the ALP spent 40 per cent of its TV budget airing the 'Just Vote 1' advertisement (anonymous campaign source).

The effect of the 'Just Vote 1' strategy was that there was a 51.99 per cent exhaustion factor in preferences from candidates running third or worse (i.e. all those candidates whose preferences were distributed). In raw terms the total exhausted vote rose from 135,427 or seven per cent of the formal vote in 1998 to 207,963 or 10.1 per cent in 2001. Thus the exhausted vote increased by 53.6 per cent from 1998 to 2001, even though there were ten seats with only two candidates and thus no exhausted votes in 2001 while in 1998 all seats were contested by at least three candidates.

The seat-by-seat effect of the 'Just Vote 1' strategy is analysed in Table 2 that lists the thirty most marginal seats with three or more candidates and calculates each seat's exhaustion rate. The actual preference flow has also been calculated and then applied to the exhausted vote. This is, of course, a large assumption because there is no clear evidence that the exhausted votes would flow in the same 
Table 1: 2001 Queensland electorates by party and two-party preferred vote

\begin{tabular}{|c|c|c|c|c|c|c|c|}
\hline Seat & Win & $2 \mathrm{pp}$ & 2nd & & & & \\
\hline Bundamba & ALP & 80.90 & LIB & Townsville & ALP & 59.33 & LIB \\
\hline Nudgee & ALP & 75.13 & LIB & MountOmman & ALP & 58.74 & IND \\
\hline BrisbaneCent & ALP & 74.96 & LIB & Mansfield & ALP & 58.62 & LIB \\
\hline SouthBrisbane & ALP & 74.93 & LIB & HerveyBay & ALP & 57.63 & ONP \\
\hline Sandgate & ALP & 74.47 & LIB & Gaven & ALP & 57.60 & NPA \\
\hline Lytton & ALP & 74.40 & LIB & Ipswich West & ALP & 57.30 & ONP \\
\hline Rockhampton & ALP & 74.18 & NPA & BarronRiver & ALP & 57.26 & IND \\
\hline Bulimba & ALP & 73.22 & LIB & Redlands & ALP & 56.86 & NPA \\
\hline Cook & ALP & 72.86 & ONP & Mudgeeraba & ALP & 56.77 & LIB \\
\hline Kurwongbah & ALP & 72.70 & LIB & Burdekin & ALP & 55.13 & NPA \\
\hline Algester & ALP & 72.63 & LIB & Aspley & ALP & 54.69 & LIB \\
\hline Stafford & ALP & 72.39 & LIB & Thuringowa & ALP & 53.56 & IND \\
\hline Logan & ALP & 72.28 & NPA & Indooroopilly & ALP & 52.88 & LIB \\
\hline Yeerongpilly & ALP & 72.18 & LIB & Kawana & ALP & 52.62 & LIB \\
\hline Inala & ALP & 71.45 & IND & Broadwater & ALP & 52.45 & NPA \\
\hline Kallangur & ALP & 71.37 & LIB & ChartersTower & ALP & 52.17 & NPA \\
\hline Murrumba & ALP & 71.12 & LIB & Clayfield & ALP & 51.98 & LIB \\
\hline Woodridge & ALP & 71.08 & ONP & ToowoombaN & ALP & 51.87 & NPA \\
\hline FernyGrove & ALP & 70.54 & LIB & Burleigh & ALP & 51.78 & NPA \\
\hline Waterford & ALP & 68.01 & ONP & Burnett & ALP & 51.70 & NPA \\
\hline Redcliffe & ALP & 67.61 & LIB & Noosa & ALP & 50.90 & LIB \\
\hline Everton & ALP & 67.46 & LIB & & & & \\
\hline Fitzroy & ALP & 67.18 & NPA & Warrego & NPA & 50.30 & IND \\
\hline Ipswich & ALP & 66.76 & ONP & Maryborough & IND & 50.50 & ALP \\
\hline Cleveland & ALP & 66.66 & LIB & Maroochydore & NPA & 50.79 & ALP \\
\hline Mountlsa & ALP & 66.23 & ONP & Moggill & LIB & 50.88 & ALP \\
\hline MountCoot & ALP & 66.12 & LIB & Caloundra & LIB & 50.96 & ALP \\
\hline Pumicestone & ALP & 66.10 & LIB & DarlingDowns & IND & 51.13 & NPA \\
\hline Chatsworth & ALP & 65.15 & LIB & Keppell & NPA & 51.46 & ALP \\
\hline Ashgrove & ALP & 65.03 & LIB & Beaudesert & NPA & 51.99 & ALP \\
\hline Bundaberg & ALP & 64.90 & NPA & Callide & NPA & 52.32 & ONP \\
\hline Cairns & ALP & 64.82 & NPA & Hinchinbrook & NPA & 52.77 & ONP \\
\hline Capalaba & ALP & 64.62 & IND & Gympie & ONP & 53.26 & ALP \\
\hline Currumbin & ALP & 64.55 & LIB & Gladstone & IND & 53.50 & ALP \\
\hline MountGravatt & ALP & 64.17 & LIB & Mirani & NPA & 53.80 & ALP \\
\hline Greenslopes & ALP & 64.09 & LIB & Robina & LIB & 54.03 & ALP \\
\hline Mackay & ALP & 63.52 & NPA & SurfersParadis & NPA & 55.29 & ALP \\
\hline Stretton & ALP & 62.66 & LIB & Lockyer & ONP & 57.30 & ALP \\
\hline Albert & ALP & 62.65 & ONP & ToowoombaS & NPA & 57.94 & ALP \\
\hline Mundingburra & ALP & 61.38 & LIB & Cunningham & NPA & 58.63 & ALP \\
\hline Mulgrave & ALP & 61.29 & ONP & Gregory & NPA & 59.30 & ALP \\
\hline Southport & ALP & 60.84 & NPA & Tablelands & ONP & 63.81 & ALP \\
\hline Springwood & ALP & 60.37 & NPA & SouthernDow & NPA & 66.77 & ALP \\
\hline GlassHouse & ALP & 59.58 & NPA & Nanango & IND & 67.07 & ALP \\
\hline Whitsunday & ALP & 59.58 & NPA & Nicklin & IND & 73.43 & ONP \\
\hline
\end{tabular}


proportions as those that did not exhaust but in the absence of other data, it is the best assumption that can be made.

The results indicate that if exhausted preferences had flowed at the rate the nonexhausted preferences actually did flow, then five seats would have changed hands. Warrego would have gone from the Nationals to an independent, Burleigh, Charters Towers and Burdekin from Labor to the Nationals and Thuringowa from Labor to an independent. So the party seat totals would have been: Labor 62 (down four), Nationals 14 (up a net two), Liberals and One Nation steady on three seats each and the independents with seven (up two).

Table 2: Marginal electorates with exhaustion rate and actual preference flow

* switch seats

\begin{tabular}{|c|c|c|c|c|c|c|c|c|}
\hline Electorate & Winner & $2 \mathrm{pp} \%$ & $\begin{array}{l}\text { 2nd } \\
\text { party }\end{array}$ & $2 \mathrm{pp} \%$ & $\begin{array}{l}\text { Exha- } \\
\text { uted }\end{array}$ & A113rd+ & Ex rate & $\begin{array}{l}\text { Actual } \\
\text { pref flow }\end{array}$ \\
\hline Warrego & NPA & 50.30 & IND & 49.70 & 4,116 & 7,976 & 51.6 & $1: 2.2^{*}$ \\
\hline Maryborough & IND & 50.50 & ALP & 49.50 & 2,852 & 5,881 & 48.5 & $6.87: 1$ \\
\hline Maroochydore & NPA & 50.79 & ALP & 49.21 & 2,770 & 4,530 & 61.1 & $2.17: 1$ \\
\hline Moggill & LIB & 50.88 & ALP & 49.12 & 2,052 & 5,184 & 39.6 & $1: 1.0444$ \\
\hline Noosa & ALP & 50.90 & LIB & 49.10 & 2,233 & 4,543 & 49.2 & $1: 1.01$ \\
\hline Caloundra & LIB & 50.96 & ALP & 49.04 & 2,972 & 5,985 & 49.6 & 1:1.097 \\
\hline DarlingDowns & IND & 51.13 & NPA & 48.87 & 3,796 & 4,749 & 79.9 & $1.569: 1$ \\
\hline Keppell & NPA & 51.46 & ALP & 48.54 & 1,778 & 3,030 & 58.7 & $2.693: 1$ \\
\hline Burleigh & ALP & 51.78 & NPA & 48.22 & 2,555 & 4,385 & 58.3 & $1: 1.966^{*}$ \\
\hline ToowoombaN & ALP & 51.87 & NPA & 48.13 & 1,907 & 3,590 & 53.1 & $1: 1.302$ \\
\hline Clayfield & ALP & 51.98 & LIB & 48.02 & 1,296 & 2,810 & 46.1 & 1:1.008 \\
\hline Beaudesert & NPA & 51.99 & ALP & 48.01 & 5,093 & 8,846 & 57.6 & $2.197: 1$ \\
\hline ChartersTower & ALP & 52.17 & NPA & 47.83 & 1,706 & 3,745 & 45.6 & $1: 2.622^{*}$ \\
\hline Callide & NPA & 52.32 & ONP & 47.68 & 4,320 & 5,694 & 75.9 & $1: 1.060$ \\
\hline Kawana & ALP & 52.62 & LIB & 47.38 & 2,166 & 4,708 & 46.0 & $1.142: 1$ \\
\hline Hinchinbrook & NPA & 52.77 & ONP & 47.23 & 6,713 & 9,117 & 73.6 & $1.238: 1$ \\
\hline Indooroopilly & ALP & 52.88 & LIB & 47.12 & 2,052 & 5,605 & 36.6 & 1.659:1 \\
\hline Gympie & ONP & 53.26 & ALP & 46.74 & 4,723 & 10,469 & 45.1 & $3.776: 1$ \\
\hline Gladstone & IND & 53.50 & ALP & 46.50 & 474 & 1,021 & 46.4 & $3.928: 1$ \\
\hline Thuringowa & ALP & 53.56 & IND & 46.44 & 3,629 & 8,052 & 45.1 & $1: 3.021 *$ \\
\hline Mirani & NPA & 53.80 & ALP & 46.20 & 4,564 & 7,004 & 65.2 & $2.271: 1$ \\
\hline Burdekin & ALP & 55.13 & NPA & 44.87 & 5,185 & 8,619 & 60.2 & $1: 2.255^{*}$ \\
\hline SurfersParadis & NPA & 55.29 & ALP & 44.71 & 1,498 & 2899 & 51.7 & $1: 1.731$ \\
\hline Mudgeeraba & ALP & 56.77 & LIB & 43.23 & 4,037 & 6,359 & 63.5 & $1.096: 1$ \\
\hline Redlands & ALP & 56.86 & NPA & 43.14 & 2,023 & 4,941 & 40.9 & $1: 3.187$ \\
\hline BarronRiver & ALP & 57.26 & IND & 42.74 & 3,321 & 8,387 & 39.6 & $1: 3.059$ \\
\hline IpswichWest & ALP & 57.30 & ONP & 42.70 & 3,131 & 6,685 & 46.8 & $1: 3.052$ \\
\hline Lockyer & ONP & 57.30 & ALP & 42.70 & 5,699 & 10,304 & 55.3 & $2.262: 1$ \\
\hline Gaven & ALP & 57.60 & NPA & 42.40 & 2,756 & 4,318 & 63.8 & 1.069:1 \\
\hline HerveyBay & ALP & 57.63 & ONP & 42.37 & 4,403 & 8,831 & 49.9 & $1: 4.197$ \\
\hline All Queensland & ALP & 54.7 & LIB/NPA & 45.3 & 207,963 & 399,983 & 51.99 & \\
\hline
\end{tabular}


It is interesting to note that if first-past-the-post-voting had been in force and preferences not considered at all, then Labor would have picked up five extra seats: Beaudesert, Cunningham and Maroochydore from the Nationals, Gympie from One Nation and Maryborough from the independent, John Kingston. Table 3 compares the seats won by each party under the optional preferential system with the number that would have been won under the compulsory preferential, first-past-the-post and strict proportional representation systems.

Table 3: Comparison of seats outcome by voting system

\begin{tabular}{lccccc} 
Party & $\begin{array}{c}\text { F First Pref } \\
\text { Votes }\end{array}$ & $\begin{array}{c}\text { Optional } \\
\text { Preferential }\end{array}$ & $\begin{array}{c}\text { Compulsory } \\
\text { Preferential }\end{array}$ & $\begin{array}{c}\text { First-past- } \\
\text { thc-post }\end{array}$ & $\begin{array}{c}\text { Proportional } \\
\text { Represent* }\end{array}$ \\
\hline ALP & 48.93 & 66 & 62 & 71 & 44 \\
\hline Liberal & 14.32 & 3 & 3 & 3 & 13 \\
\hline National & 14.16 & 12 & 14 & 9 & 53 \\
\hline One Nation & 8.69 & 3 & 3 & 2 & 8 \\
\hline Greens & 2.51 & 0 & 0 & 0 & 2 \\
\hline CCAQ** & 2.39 & 0 & 0 & 0 & 2 \\
\hline Independent & 8.61 & 5 & 7 & 4 & 8 \\
\hline
\end{tabular}

*Rounded to nearest whole number thus adds to 90

**City Country Alliance Queensland

\section{Conclusion}

While in the end the 'Just Vote 1' strategy was only of minor consequence to the election outcome, it is clear that if the election had been a cliff-hanger then the strategy would have been of much more consequence. The strategic advocacy of optional preferential voting by political parties raises some important questions about the representativeness and therefore the legitimacy of governments elected with what may be less than majority support.

Of course the issue of representation is problematic in all parliamentary systems based on single member constituencies. As Table 3 shows, single member systems are not good at reflecting proportional support for parties across the whole electorate, particularly in a landslide situation. A further problem has become evident as party campaigns become more proficient at persuading the swinging voters in marginal seats to support them. Effective marginal seats campaigning can return a government 
majority, even though a majority of voters, many 'locked away' in safe seats, might oppose the government. Thus in Queensland in July 1995, the Labor government was returned with 46.7 per cent of the two party preferred vote (Green 1995: 13).

The continued strategic use of optional preferential voting is another problem for representation. In recommending the introduction of optional preferential voting in Queensland, EARC (1990: 59) said that '[e]ncouraging voters to express preferences is ultimately a matter for candidates and parties, not the electoral system.' The question must now be raised as to whether parties encouraging voters not to express preferences in fact defeats the purpose of preferential voting: to ensure that governments are representative of the majority. Reilly (1997: 6) claims that previous experiments with optional preferential voting in Australian states and Canadian provinces have been 'abandoned' precisely because 'voters used their vote to "plump" for one candidate rather than expressing preferences, thus effectively turning the election into a first-past-the-post contest.'

It is interesting to note the opinion of High Court Justices Toohey and Gaudron in Longer $v$ Commonwealth of Australia (1996 134 ALR 400). The case arose when Albert Langer advocated a method of optional preferential voting in federal elections by making a valid primary vote and then writing ' 2 ' against all the other candidates and thus forcing their vote to exhaust. The Commonwealth went to great lengths to prevent the advocacy of such a vote and in finding against Langer, Toohey and Gaudron claimed that full preferential voting 'was a more democratic method' (Eraser 1996: 86) than the optional preferential method advocated by Langer (or, one is left to assume, the methods in force in New South Wales and Queensland).

There is a concern that optional preferential voting might weaken the agency link between constituent and politician and make it harder for the former to collectively sanction the latter (Mitchell 2000). In fact in the 2001 Queensland state election, 29 successful candidates were returned with a majority of the unexhausted vote but less than an absolute majority of the formal vote. This is hardly surprising given the high rate of exhausted votes but it does undermine the claim of almost a third of Queensland parliamentarians to actually represent their constituents.

The question remains: is optional preferential voting good for democracy? There appears to be a growing international appreciation that preferential voting 'fosters' democracy (Horowitz 1990) so one must wonder whether anything that draws our electoral system back towards first-past-the-post voting is diluting the force of majority rule and democratic legitimacy. 


\section{STEPHEN STOCKWELL}

\section{References}

Adams, D. 1979, 'New South Wales - Electoral reform'. Australian Quarterly, 51. June: 110-111. Black, D. 1958, The theory of committees and elections, Kluwer Academic Publishers, Boston.

Electoral and Administrative Review Commission (EARC) 1990, Report on Queensland Legislative Assembly Electoral System 1 volumes, EARC, Brisbane.

Electoral Commission of Queensland (ECQ) 2001, Queensland Election 2001: Statistical Returns, ECQ, Brisbane.

Franklin, M. 2001, 'Voters confused by party dealing', Courier-Mail, 24 January: 8.

Fraser, C. 1996, 'Plastic rights: reading the freedom of political communication out of Langer v Commonwealth of Australia and Others', Ormond Papers, 13: 77-90.

Green, A. 1995, 'Why the odds are against Labor. Sydney Morning Herald, 18 Setember: 13.

Horowitz, D. 1990, 'Presidents vs. parliaments: Comparing democratic systems', Journal ofDemocracy 1(4), Fall: 73-79.

Mitchell, P. 2000, 'Voters and their representatives: electoral institutions and delegation in parliamentary democracies', European Journal of Political Research 37(3), May: 335-351.

Reilly, B. 1997, 'Preferential voting and political engineering: a comparative study', Journal of Commonwealth and Comparative Politics, 35(1): 1-19.

Wanna, J. 1999, 'Queensland' The Australian Journal of Politics and History 45(4): 572.

Wright, J.F.H. 1980, Mirror of the Nation's Mind: Australia's Electoral Experiments, Hale \& Iremonger, Sydney. 